\title{
Perspectives on digital education - or should we rethink teaching?
}

\author{
Mária Jaskóné Gácsi
}

\begin{abstract}
The rapid development of digital technology in recent decades can also be followed up in the effectiveness and extent of learning. The only question is how to maximize the use of technology to increase learning efficiency, how to support differentiated education, increase student concentration, and maintain persistence and motivation. Digital learning makes students more motivated and accountable. Students using digital learning tools and technology are increasingly involved in the process and their knowledge base grows through their interest, furthermore they are not even aware that they are actively learning as education takes place through attractive methods such as teamwork, problem solving, mind maps, gaming, directing, role-playing and storytelling. Because digital learning is much more interactive and memorable than textbook-based or frontal lectures, it provides a better context, a greater sense of perspective, and more engaging activities than traditional teaching methods. This allows students to be more connected to the educational material. They often offer a more interesting way to digest the information, which is also reflected in the test results. In addition, you can improve motivation if students can track their own progress.
\end{abstract}

Keywords: digital education; gamification; creativity; method; COVID-19

Subject-Affiliation in New CEEOL: Social Sciences - Education - School Education

DOI: $10.36007 /$ eruedu.2020.3.018-024

The rapid development of digital technology in recent decades can also be followed up in the effectiveness and extent of learning. The only question is how to maximize the use of technology to increase learning efficiency, how to support differentiated education, increase student concentration, and maintain persistence and motivation.

An important recent result is that the possibilities offered by technology changed the size and quality of the databases concerning the complex phenomenon of studying. This progress has encouraged a qualitative change in previous theories and practical methods, as well as the development of new theories and methods. This questioning and answering of new research topics facilitated a deeper understanding of learning processes. 
There is great potential for the use of mobile devices, serious games and simulations in primary and secondary education, as well as for the spread of MOOC applications in higher education and for the advantages of the use of "big data" and learning analysis. (Molnár, Turcsányi-Szabó, \& Kárpáti, 2020.)

Digital education is replacing traditional teaching methods day by day. Because classroom technology is changing rapidly, it is the best to say goodbye to the old methods which they have relied on in the past, and at the same time open up to digital learning tools and technologies, mastering newer teaching and learning techniques.

The application of digital learning can vary from classroom to classroom, depending on whether tablets are used instead of papers, so as opposed to simple stationery, complex software programs and tools can also take place. This can include a range of web sites, services, programs, educational tools and technologies, such as tools designed for home use. Even social networks and communication platforms can be used to create and manage digital tasks and agendas.

No matter what kind of technology is incorporated into the classroom work schedule, digital learning plays a crucial role in education. All of this can make students much more motivated to learn and broaden their horizons. Educational tools and technology allow students to develop effective self-directed learning skills. They are able to identify what they need to learn, find and use online resources, apply information about the current problem, and even evaluate the feedback they receive, thereby increasing their effectiveness.

In addition to involving students, digital education tools improve the ability to think critically, which is the basis for developing analytical reasoning. Children who explore open-ended questions with imagination and logic, learn how to make decisions, as opposed to the textbook's inspired comments. Interactive skill games are excellent learning tools that teach children the discipline that is essential to play as well, as they have to follow rules and guidelines to participate. Even children who have failed other learning methods can cling to games for longer because the game itself pays off as well. It also helps them to develop patience.

Digital learning makes students more motivated and accountable. Students using digital learning tools and technology are increasingly involved in the process and their knowledge base grows through their interest, furthermore they are not even aware that they are actively learning as education takes place through attractive methods such as teamwork, problem solving, mind maps, gaming, directing, role-playing and storytelling. Because digital learning is much more interactive and memorable than textbook-based or frontal lectures, it provides a better context, a greater sense of perspective, and more engaging activities than traditional teaching methods. This allows students to be more connected to the educational material. They often offer a more interesting way to digest the information, which is also reflected in the test results. In addition, you can improve motivation if students can track their own progress.

Digital learning tools and technology are rapidly increasing by information sharing. In recent years, the transition from printing to digital has influenced the way we learn. Just like in the printing press six centuries ago, this transition is transforming 
formal education and increasing learning opportunities. Digital learning not only allows students to access more and more information, but also allows the information in question to be customized and tailored to their personal needs. The most important benefit of digital learning is that it helps all students to learn at the best possible pace and in the best possible way.

Traditional lectures can still be sustained along with modern learning tools and technologies, but lecture materials should be interpreted as complementary to classroom activities and placed online for reference by students outside the classroom. Classroom time can be better used to discuss the curriculum, work with groups, and complete class projects. By helping children think outside of typical learning styles, digital learning encourages creativity and allows children to feel encouraged to continue learning.

Digital devices and technological advances can have positive effects to traditional classroom education. In addition to environmental impact like less paper use, it is also time saving, and gives fast access to information through simplicity of research, cost reduction, and maximization of resources. These all contribute to a positive approach to digital education. (Panworld Education, 2017)

\section{Gamification as a possible way of digital learning}

Today, schools face significant challenges in motivating and engaging students. Gamification, that is the incorporation of elements of play into the out-of-play processes of life, allows schools to remedy these problems.

Gamification, first used as a conceptual definition by Nick Pelling in 2002, attempts to exploit the motivational power of games and apply it to real-world problems such as motivational problems in schools. (Lee \& Hammer, 2011.)

Effective games usually involve a series of goals or steps, clear rules, a story, interactivity, and constant feedback, including some reward. They can also incorporate social elements of teamwork and communication. Games can improve students' attention and motivation, and provide students with the freedom to try, fail, and explore. 
Pros

It supports curiosity and experimentation.

It helps to have a positive attitude towards failure

It can provide individual learning appropriate to the level and pace of students.

It can improve attention
Cons

Not all learning can be based on games

Gamification must be balanced with other educational approaches

It can distract someone if it is not closely related to the learning goals

It can encourage external motivation rather than internal motivation

(Australian Government Department of Education, Skills and Employment, 2019.)

The gap between the generations, caused in part by the information technology revolution, has posed a challenge to educators and educational institutions. In Hungary, the growing competitive situation, the expanding knowledge base and the changes in educational needs necessitated the introduction of new methods.

The listed processes have been going on for decades, but lastingly effective solutions that would have been rooted in the entire education system are seldom found in isolation. At the same time, the information technology revolution, which is the cause of the digital divide, has brought many solutions. The gaming industry is a relatively young sector that needs to use the most sophisticated motivational elements to succeed and is therefore most interested in developing these elements.

Both analogue and digital games have created a huge market, so the number of users is significant in almost all walks of life. By the 21 st century, some researchers have recognized that motivational procedures in game development can be applied with similar success to other non-player frameworks, such as lesson planning. In recent years, more and more high-quality products are emerging in increasing numbers, specifically designed to help develop certain abilities, knowledge or skills.

There is also an increase in the number of games specifically designed for school use, and many studies also demonstrate the skill-building nature of mainstream games. In schools, games have typically played a complementary role so far, with educators thinking of them mostly as a deductible, relaxing task or reward. Now, however, it has become possible for students to master parts of the course by directly engaging in a game.

Player systems play an extremely important role in feedback and evaluation processes. As Lee Sheldon pointed out, even the simplest point and level systems can have an extremely strong impact on participating students and teachers. One of the great advantages of point systems is that they focus primarily on development and accumulation. As long as the traditional ticket-based evaluation calculates the averages (based on the results collected during the year), the points provide an opportunity to perceive and observe progress, which also increases motivation. In addition to scoring systems, for example, it is recommended to integrate levels, badges, or various available tasks (so-called missions) into rating systems, which only take effect once a certain score has been reached, so this element represents a kind of delayed or medium-term feedback. Badges or certificates, on the other 
hand, implement a specific event. For example, if a student completes a special task or reaches a certain level, the system may reward him or her with a special badge.

In international pedagogy, teachers have been using various play methods and interfaces for years, but there are already teachers in Hungary who can report on their own experiences related to the introduction and use of play mode. Below I would like to list some learning game technology systems that have proven to be a proven method based on experience.

ClassDojo is a classic digital classroom that helps with the educational process. It also involves students, teachers, and parents in a single system, offering them the opportunity to build on a variety of challenges, provide rewards, and provide real-time feedback. Students create an avatar and then further develop it with their activities.

GoalBook is an application that facilitates interaction between students, especially teamwork. It provides an opportunity for communication between teachers, parents and students and for monitoring student progress.

The Classcraft semi-playful, semi-educational (i.e., playful and fun) teaching method was invented by high school teacher Shawn Young in 2014 to make classes more interesting for students. It is an educational online interface based on the elements and operation of the best known multiplayer online role-playing game, World of Warcraft, where each student can select a character (such as a wizard, warrior, or healer) and where the adventure master is the teacher himself. In addition to the choice of roles and the challenges associated with a given story, the ranking system also comes into play, as traditional scores in the program are replaced by the system of XP points (experience points) known in online games.

\section{The current situation of digital education in Hungary}

Digitalization means competitiveness, it is the key to increase well-being, therefore the Hungarian Government is committed to digital development. Based on the 2015 National Consultation on internet and digital development projects initiated by the government, (InternetKon) citizens expressed their unanimous wish about the future of internet in Hungary: it should be available and at a decent price for all, it should assist education and cannot present a danger for the safety of the underage. According to the results of the InternetKon survey the government created the Digital Success Programme (DSP) that aims for the digital improvement of the Hungarian society and economy. The programme, including the Digital Education Strategy of Hungary (DES) is based on the fact that digital transformation is not a choice, it is unavoidable, and everyone has to be prepared for it as competitiveness in the 21st century cannot be achieved with 20th century knowledge. Digital technology and approach has to be introduced in the classrooms as they have been integrated in our everyday lives deeply. Digital tools and approach has to be introduced in classrooms as they are getting more and more integrated in our everyday life. It is impossible to teach and learn in the 21 st century with tools 
and methods used in the previous century. DSP is of priority in the development of Hungary's digital educational strategy. To achieve this it is necessary to alter our social paradigm. It is of importance to ensure that education facilitates a sort of knowledge and a connection with everyday life. The future school should be a kind where students and teachers alike acquire skills connected to digital tools. The aim is that the digitally educated teachers use digital methods and learning materials, and the school management and teachers are further training is based on digital technology. Similarly fundamental that digital education should not be a digital version of the same traditional education supported by digital tools. An open environment has to be created that facilitates new approaches, methodology and requirements responding to the challenges of the new era. (Deutsch, 2016.)

\section{Digital education vs corona virus}

The COVID-19 pandemic caused a dilemma to education, however, opened up opportunities to the spread of digital education. Worldwide more than 1,2 billion children left the classrooms. As a result education changed dramatically, the traditional classroom learning was replaced by e-learning so teaching happened through digital platforms.

Educational institutions in Hungary were subject to distance education from 13 March 2020 by government regulations, and so new guidelines were implemented in practice. Teachers had to face a situation that many could not cope with, in spite of the fact that the Secretary of State for Public Education announced digital education introduced in the pandemic as a success. Why couldn't they? In most schools there was no practice of digital education despite the given conditions like IWB, tablets, applications, etc. Most of the teachers are middle aged or are about to retire so they are not as receptive, or rather resistant. However, in these cases the pandemic forced them to consider the teaching techniques. Many could adapt to the situation and made the most of it by using different software, applications and digital classrooms so that they could continue the work. After a while Classroom, Kréta-system (Public Registration and Educational System), E-learning, Zoom, Moodle, Skype were not new to them. The most common is KRÉTA, which is an effective support to home based learning, to communication with students/parents and to online education. The KRÉTA-system enables to control students' home based learning, and teachers can easily share documents in the World Wide Web. (Tools supporting distance learning and the KRÉTA-system, 2020.)

However, there were some who did not manage to get this far. They sent the materials in email to their students hoping that parents will be part of the learning process. The teacher's competence and skills or lack of it are just one of the conditions to make digital education work. To make it happen there was a necessary condition to exist: is there a laptop or a tablet at home for the student to participate in the digital education? If yes, how well can they use it, do they have to share with siblings or family members? If no, then what other methods can be implemented to assist the student? Unfortunately, there are many disadvantaged students and it is 
uncertain how they will recover these months as in their case the bread and butter is the question, not digital technology. In their case digital education increases their disadvantage which a teacher should somehow manage from September.

Researches prove, however, that those who have had access to digital technology, learning in this way may have been more effective in many ways. Some of the researches show that students processed an average of $25-60 \%$ more materials online compared to $8-10 \%$ in the classroom. The reason first of all is that students learn faster on the internet. E-learning takes up to $40-60 \%$ less time than traditional classroom environment as students can learn at their own pace, repeat, skip or speed up the material. Despite all this, the effectiveness varies according to age groups. Especially in case of younger children researchers agree that there is a need for structured environment as they can be distracted easily. To make the most of online learning, concentrated effort has to be made to ensure this structure. (The COVID-19 pandemic has changed education forever. This is how, 2020.)

To sum up, digital education in Hungary is still at an early stage despite the fact that strategies work in theory. We can talk about problems of course mainly in public education as in higher education distance learning is not a new phenomenon.

\section{References}

A távoktatást támogató eszközök és a KRÉTA-rendszer. (2020.. március 25.). Letöltés dátuma: 2020. július 9., forrás: Oktatási Hivatal: https://www.oktatas.hu/kozneveles/ ajanlas_tantermen_kivuli_digitalis_munkarendhez/tavoktatast_tamogato_eszkozok_kreta_rendszer

Australian Government Department of Education, Skills and Employment. (2019.). Letöltés dátuma: 2020.. július 8, forrás: https://www.education.gov.au/national-stem-education-resources-toolkit/gamification: https://www.education.gov.au/national-stem-education-resources-toolkit/gamification

Deutsch, T. (2016.. június 30.). Digitális Jólét Program,MAGYARORSZÁG DIGITÁLIS OKTATÁSI STRATÉGIÁJA . Budapest, Pest, Magyarország. Letöltés dátuma: 2020. július 8., forrás: https://www.kormany.hu/download/0/cc/d0000/MDO.pdf

Fomann, R., \& Damsa, A. (2016). A gamifikáció (játékosítás) motivációs eszköztára az oktatásban. Új Pedagógiai Szemle.

Lee, J. J., \& Hammer, J. (2011.). Gamification in Education: What, How, Why Bother? Academic Exchange Quarterly.

Molnár, G., Turcsányi-Szabó, M., \& Kárpáti, A. (2020.). Digitális forradalom az oktatásban Perspektívák és dilemmák. Magyar Tudomány, 56-67.

Panworld Education. (2017.. március 23.). Letöltés dátuma: 2020.. július 8., forrás: BENEFITS OF DIGITAL LEARNING OVER TRADITIONAL EDUCATION METHODS: http://www. panworldeducation.com/2017/03/23/benefits-of-digital-learning-over-traditional-education-methods/

The COVID-19 pandemic has changed education forever. This is how. (2020.. április 29.). Letöltés dátuma: 2020.. július 10., forrás: World Economic Forum: https://www.weforum.org/agenda/2020/04/coronavirus-education-global-covid19-online-digital-learning/ 